\title{
Effects of Marine Toxin Domoic Acid on Innate Immune Responses in Bay Scallop Argopecten irradians
}

\author{
Cheng Chi ${ }^{*}{ }^{\dagger}$, Caiyan Zhang ${ }^{\dagger}$, Jiadai Liu and Xiaochuan Zheng \\ Key Laboratory of Aquatic Nutrition and Feed Science of Jiangsu Province, College of Animal Science and \\ Technology, Nanjing Agricultural University, No. 1 Weigang Road, Nanjing 210095, Jiangsu Province, China; \\ 2018105050@njau.edu.cn (C.Z.); 2017105048@njau.edu.cn (J.L.); 15951977892@163.com (X.Z.) \\ * Correspondence: chicheng0421@126.com; Tel.: +86-25-84395270; Fax: +86-25-84395382 \\ + These authors contributed equally to this work.
}

Received: 12 October 2019; Accepted: 21 October 2019; Published: 9 November 2019

\begin{abstract}
Domoic acid (DA) is an amnesic shellfish poisoning toxin produced by some species of the genera Pseudo-nitzschia and Nitzschia. This toxin has harmful effects on various species, especially scallops. This study aimed to investigate the effects of DA exposure on the immune and physical responses of bay scallop, Argopecten irradians. Various immunological and physical parameters were assessed (acid phosphatase (ACP), alkaline phosphatase (ALP), lactate dehydrogenase (LDH), lipid peroxide (LPO), nitric oxide (NO), and the total protein content) in the haemolymph of scallops at 3 , $6,12,24$, and $48 \mathrm{~h}$ post-exposure to DA at different concentrations (10,50, and $100 \mathrm{ng} / \mathrm{mL})$. Moreover, the expression of immune-related genes (CLT-6, FREP, HSP90, MT, PGRP, and PrxV) was assessed. The activities of ACP, ALP, and LDH and the total protein content and LPO increased upon exposure to DA at different concentrations, while NO levels were decreased. Furthermore, immune-related genes were assessed upon DA exposure. Our results showed that exposure to DA negatively impacts immune function and disrupts physiological activities in bay scallops.
\end{abstract}

Keywords: Domoic acid; bay scallop; Argopecten irradians; harmful algal blooms; immune response

\section{Introduction}

Harmful algal blooms, caused by environmental changes and water pollution, have harmful effects on various organisms including humans, not only affecting the coastal ecology, but also causing serious economic losses [1]. One prominent underlying reason is that harmful algal blooms produce marine phycotoxins and other metabolites [2]. Domoic acid (DA) is an amnesic shellfish poisoning (ASP) toxin, produced naturally by some species of the genera Pseudo-nitzschia and Nitzschia [3]. DA is an amino acid with three carboxyl groups and one amino group, and is structurally similar to glutamic acid and kainic acid [4]. Glutamate is a putative excitatory neurotransmitter in the vertebrate central nervous system [5]. Because of this structural similarity, DA binds to the glutamate receptor [GluRs] family to induce neuroexcitatory and neurotoxic effects [6]. DA exerts neurotoxic effects on the central nervous system of mammals and other vertebrates [4,7]. These investigations focused on mice, humans, birds and others, revealing the neurovirulence of DA, which included brain injury, acute retina injury and age and gender susceptibility [1,2], exposure routes for vertebrates, and vertebrate susceptibility [3]. Although few researchers studied marine organisms including fish and marine mammals, they only revealed the susceptibility $\left(\mathrm{ED}_{50} / \mathrm{LD}_{50}\right)$ to $\mathrm{DA}$, aggressive behavior, swimming behavior, and metabolic activity in brain of marine mammals and fish [4]. Moreover, many other studies have focused on the morphology, distribution, and toxicity of DA producing algae species including 
Pseudo-nitzschia spp., Nitzschia bizertensisand, and Nitzschia navis-varingica [5]. Although there are some investigations related to invertebrates, most of them reported that the DA content accumulated in the various tissues as the important DA vectors to top predators, whereas fewer have documented toxicological effects on themselves resulting from exposure [5]. Generally, the immunotoxic potential of DA, a well-characterized neurotoxin, has not been fully investigated. The previous results in mice suggest that DA may exert its immunotoxic effects both directly and indirectly by affecting monocyte phagocytosis [6]. Bivalves, including scallop Argopecten irradians, are among the important marine fishery resources in China, South Korea, and Japan. Bivalves are filter-feeding organisms, therefore, biotoxins produced during harmful algal blooms can accumulate in their body tissues [8]. However, there are great physiological differences between vertebrates and invertebrates, in case of the immune system.

Scallops, as an invertebrate, lack adaptive immunity and rely primarily on the innate immune system for their defense [9], and humoral components mediate innate immunity primarily via the haemolymph. Acid phosphatase (ACP) and alkaline phosphatase (ALP) are important lysosomal enzymes which are involved in humoral immune responses and participate in the degradation of foreign carbohydrates, proteins, and lipids [10,11]. They are primarily present in lysosomes of granulosa cells and contribute to phagocytosis and secretion into the serum through degranulation [12]. Lactate dehydrogenase (LDH) is a soluble cytosolic enzyme that potentially reflects damage to cells, tissues, and organs [13]. Lipid peroxide (LPO) is the product of the reaction between oxygen free radicals and polyunsaturated fatty acids, and increased LPO levels potentially indicate structural or functional damage to cells or cell membranes [14]. Nitric oxide (NO) is widely distributed in various organs and participates in many important physiological and pathological activities such as immune defense [15]. It is synthesized by inducible (i) NO synthase (iNOS), and usually considered to be related to the immune response in mammals. In bivalves, NO has been demonstrated that it is involved in innate immunity, iNOS-like activity has been detected in hemocytes of the zhikong scallop Chlamys farreri after LPS stimulation $[9,16]$, and NO has been shown be synthesized in scallop hemocytes [17], directly or indirectly contributing to pathogen elimination [11]. It is also been demonstrated that NO promotes apoptosis, phagocytic and anti-bacterial ability by developing oxidative toxicity in order to avoid excessive auto-toxicity during the last phase of immunity, playing a crucial role in the modulation of the immune response $[9,11]$. Therefore, the innate immune-related responses of scallops exposed to DA can be understood through the assessment of these immune-related parameters.

Generally, this study aimed to investigate the effects of DA exposure on the immune and physical responses of bay scallop by measuring the activities of ACP, ALP, LDH, and contents of NO, LPO as well as the expression of immune-related genes in bay scallop after different concentrations of DA exposure. The results of current study will provide a novel insight into the immunotoxicity of DA in scallops, and the present results also are of particular interest and use to toxicologists and researchers involved in studies on cellular and molecular toxicity of xenobiotics [18].

\section{Materials and Methods}

\subsection{Domoic Acid}

Domoic acid (DA), 90-100\% on HPLC, was purchased from Sigma-Aldrich Co. LLC (Sigma, St. Louis, MO, USA) and stored at $4^{\circ} \mathrm{C}$ in a refrigerator until use.

\subsection{Animals}

Three hundred and sixty bay scallops were collected by a fisheries wholesale market in Jiangsu Province, China. The average shell length of the scallops was $59-70 \mathrm{~mm}$; average weight, $45.32+2.43 \mathrm{~g}$. Before the experiments, the scallops were stored in lantern nets suspended in an 800-litre container supplied with filtered and aerated seawater for two weeks to adapt to laboratory conditions (tempreture: $10 \pm 1{ }^{\circ} \mathrm{C}$; salinity: $30 \%$ o $\pm 0.1 \%$ o). Instant Algae ${ }^{\circledR}$ Shellfish Diet (Reed Mariculture 
Inc., Campbell, CA, USA) was fed to scallops with $1.2 \times 10^{10}$ algal cells per scallop. Half of seawater was changed daily.

The bay scallops were distributed as four groups: control group and three treatment groups (DA exposure). Each group comprised 30 scallops with 3 replicates. The DA stock solution was prepared by dissolving DA in millipore water, and the equal volume of millipore water was added in the control. The experimental groups were exposed to DA at four concentrations $(0,10,50$, and $100 \mathrm{ng} / \mathrm{mL})$, which were selected on the basis of previous studies reporting the toxicity of DA accumulation and its effects on juvenile scallops [19]. To maintain the DA concentrations, no water exchange or tank cleaning was performed during this experiment. One millilitre of haemolymph was sampled from each bay scallop at $3,6,12,24$, and $48 \mathrm{~h}$ upon exposure to DA. Three scallops per group were used as triplicates. The haemolymph sampled from each group was divided into two parts: one part $(100 \mu \mathrm{L})$ was used to extract RNA, and the other part was centrifuged for $3 \mathrm{~min}$ at $750 \times \mathrm{g}$ and stored at $-80^{\circ} \mathrm{C}$ to measure the humoral immune parameters. This present study was approved by the Animal Care and Use Committee of Nanjing Agricultural University (Nanjing, China) (permit number: SYXK (Su) 2017-0007).

\subsection{Measurement of Non-Specific Immune Responses}

ACP and ALP activity in the haemolymph were quantified using assay kits (Nanjing Jiancheng Bioengineering Institute, China). The unit definition of ACP enzymatic activity corresponded to $1 \mathrm{mg}$ nitrophenol within $30 \mathrm{~min}$ at $37^{\circ} \mathrm{C}$ according to the instruction of the commercial kit. One microgram of phenol was released per $100 \mathrm{~mL}$ haemolymph, corresponding to one unit of ALP activity according to the instruction of the ALP assay kit.

Lactate dehydrogenase (LDH) in haemolymph was quantified using an assay kit (Nanjing Jiancheng Bioengineering Institute, China). LDH catalyzes the synthesis of pyruvic acid from lactic acid, and pyruvic acid reacts with 2,4-dinitrophenylhydrazine to produce pyruvic dinitrophenylhydrazine. The product is reddish brown in an alkaline solution. The activity of the enzyme was determined by measuring the absorbance at $450 \mathrm{~nm}$.

NO levels were determined using the nitrate reductase assay using an assay kit (Nanjing Jiancheng Bioengineering Institute, China). NO is oxidized to nitrate and nitrite by oxygen and then reacts with the chromogenic agent to generate azo dyes, which can be quantified using a spectrophotometer.

LPO and the total protein content in haemolymph were estimated using assay kits (Nanjing Jiancheng Bioengineering Institute) in accordance with the manufacturer's instructions.

\subsection{Real-Time Quantitative PCR Analyses of Gene Expression}

Total RNA was extracted using TRIzol Reagent from haemolymph samples [11]. The concentration and purity of RNA were determined using a spectrophotometer, based on the OD 260/280 values $(1.8<$ ratio $<2.0)$. cDNA was synthesized using a PrimeScript ${ }^{\mathrm{TM}}$ RT Reagent Kit (TaKaRa Bio, Otsu, Japan) in accordance with the manufacturer's instructions and stored at $-80{ }^{\circ} \mathrm{C}$ for the real-time quantitative PCR (qPCR).

qPCR was performed using SYBR Premix Ex Taq ${ }^{\mathrm{TM}}$ Kits (TaKaRa Bio) on a RT-PCR Detection System (Qiagen, Hilden, Germany). Gene expression was standardized by $\beta$-actin. The sequences of primers for the target and reference genes (CLT6, FREP, HSP90, MT, PGRP, PrxV and $\beta$-actin) are enlisted in Table 1. The reactions proceeded at a final volume of $12 \mu \mathrm{L}$, containing $6.25 \mu \mathrm{L}$ SYBR Premix Ex Taq ${ }^{\mathrm{TM}}, 1 \mu \mathrm{L}$ forward primer, $1 \mu \mathrm{L}$ reverse primer, and $1 \mu \mathrm{L}$ cDNA and ultra-pure water. The cycling conditions were as follows: a pre-run at $95{ }^{\circ} \mathrm{C}$ for $10 \mathrm{~min}$, followed by 40 cycles at 95 ${ }^{\circ} \mathrm{C}$ for $45 \mathrm{~s}, 56{ }^{\circ} \mathrm{C}$ for $45 \mathrm{~s}$, and $72{ }^{\circ} \mathrm{C}$ for $30 \mathrm{~s}$. After the amplification stage, the melting curve was analysed. The relative mRNA levels were determined using the $2^{-\Delta \Delta C T}$ method [20]. In all cases, PCR was performed in triplicate. 
Table 1. Primers used for the analysis of mRNA expression via qRT-PCR analysis.

\begin{tabular}{lll}
\hline Genes & Primer Sequence & Accession No. \\
\hline \multirow{2}{*}{-actin } & F:5'CAAACAGCAGCCTCCTCGTCA 3' & AY335441 \\
& R: 5'CTGGGCACCTGAACCTTTCGTT 3' & \\
CTL6 & F' 5'CAGTTGCTACAGGGTTCG 3' & GQ202279 \\
& R: 5'GGGCGTTATCTGGCTCAT 3' & \\
FREP & F: 5'CGTCGCAAATGCTGAAGATG 3' & EU399719 \\
& R: 5'TAAGTTGTGGTCGGTCCTGAGA 3' & \\
HSP90 & F: 5'TCAGTATGGTTGGTCCGCTAA 3' \\
& R: 5'CGGTTGCCTTTCCTTCAGA 3' & EF532406 \\
MT & F: 5'AACTTGCTGTAGTGGGAATG 3' & \\
& R: 5'AGGCTGGAAACTGCTGTGGT 3' & EU734181 \\
PGRP & F: 5'GGGCAAGTGTATGAGGGAAGAG 3' & \\
& R: 5'TCCGATGAAGGAGACAGCGTAG 3' & AY437875 \\
& F: 5'AATCAAGGAGCGGCTGGCA 3' & \\
& R: 5'TCAACTTCTCAATCTTCCCGTCAT 3' & HM461987 \\
\hline
\end{tabular}

\subsection{Statistical Analyses}

The data were tested for normality and homogeneity of variance, using the Kolmogorov-Smirnov and Cochran's tests. Data were analyzed using one-way analysis of variance (ANOVA). The data were presented as mean \pm standard deviation (SD) values. The differences were determined using the LSD test in the SPSS 19.0 software (IBM Corp., Armonk, NY, USA) with $p<0.05$ indicating statistical significance.

\section{Results}

\subsection{Non-Specific Immune Responses}

\subsubsection{ACP Activity}

ACP activity (Figure $1 \mathrm{~A}$ ) was significantly enhanced in $10 \mathrm{ng} / \mathrm{mL}$ of DA treated group at $3-24$ hours post exposure (hpe) comparing with control, and the highest level of ACP activity was observed at 3 hpe. In $50 \mathrm{ng} / \mathrm{mL}$ of DA treated group, an obvious enhancement in ACP activity was observed at 3-12 hpe. ACP activity was significantly increased in $100 \mathrm{ng} / \mathrm{mL}$ of DA treated group at 3-48 hpe except for 24 hpe.

\subsubsection{ALP Activity}

ALP activity (Figure 1B) was significantly enhanced in $10 \mathrm{ng} / \mathrm{mL}$ of DA treated group at 3-48 hpe. ALP activity was significantly raised in the $50 \mathrm{ng} / \mathrm{mL}$ DA-treated group at all time intervals. In the group treated with $100 \mathrm{ng} / \mathrm{mL}$ of DA, ALP activity was increased at 3-24 hpe and reverted to baseline levels up to 48 hpe.

\subsubsection{LDH Activity}

LDH activity (Figure 1C) was significantly increased in the group treated with $10 \mathrm{ng} / \mathrm{mL}$ of DA at 3-12 hpe and then reverted to baseline levels at $24-48 \mathrm{hpe}$. LDH activity was significantly increased in the 50 and $100 \mathrm{ng} / \mathrm{mL}$ DA-treated groups at 3-24 hpe and then reverted to baseline levels at $48 \mathrm{hpe}$.

\subsubsection{LPO Level}

LPO levels (Figure 1D) were significantly increased in all DA-treated groups at all time intervals. 


\subsubsection{NO Level}

NO levels (Figure 1E) were significantly decreased at all time intervals upon exposure to 10, 50, and $100 \mathrm{ng} / \mathrm{mL}$ of DA.

\subsubsection{Total Protein Concentration}

The total protein concentration (Figure 1F) was significantly increased in the 50 and $100 \mathrm{ng} / \mathrm{mL}$ DA-treated groups at all time intervals. In the group treated with $10 \mathrm{ng} / \mathrm{mL}$ of DA, the total protein concentration was significantly increased at 3-12 hpe and reverted to baseline levels at 24-48 hpe.
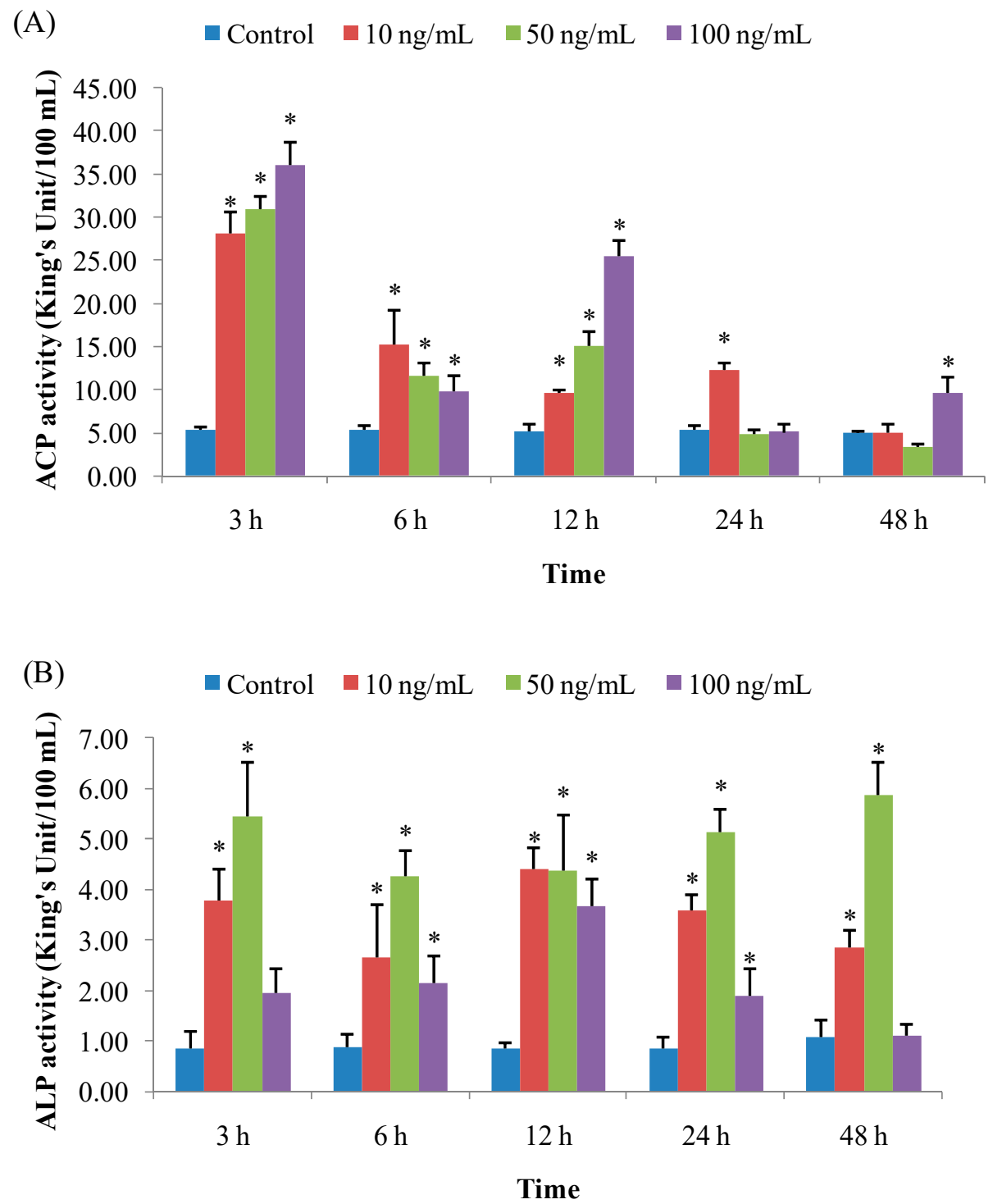

Figure 1. Cont. 
(C)

- Control $\quad \square 10 \mathrm{ng} / \mathrm{mL} \quad \square 50 \mathrm{ng} / \mathrm{mL} \quad \square 100 \mathrm{ng} / \mathrm{mL}$

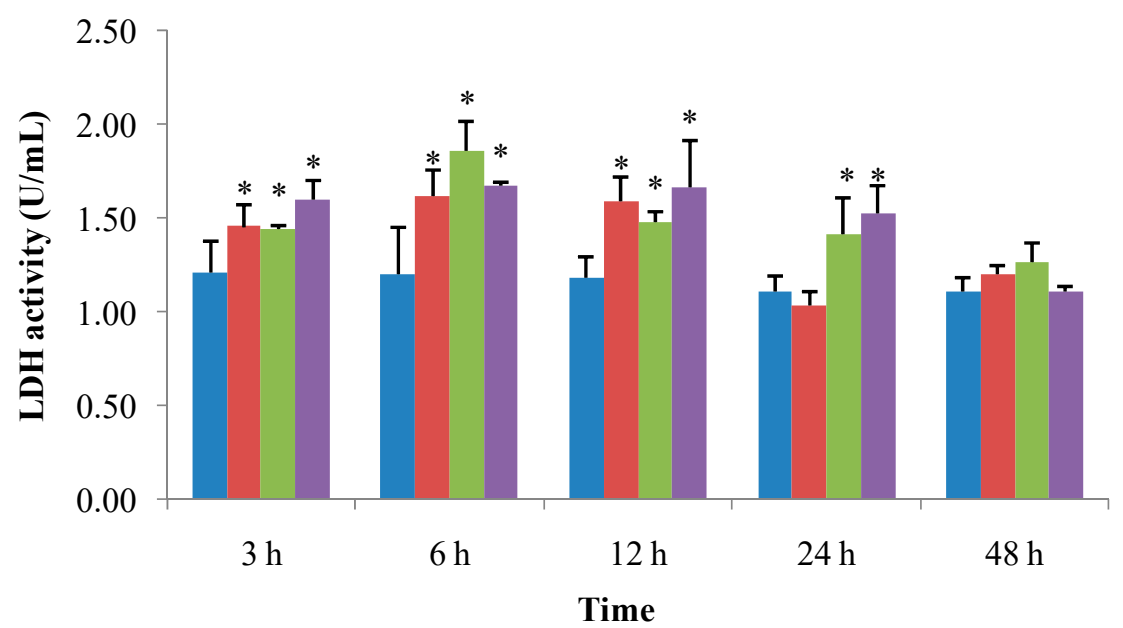

(D) $\quad$ Control $\quad \square 10 \mathrm{ng} / \mathrm{mL} \quad \square 50 \mathrm{ng} / \mathrm{mL} \quad \square 100 \mathrm{ng} / \mathrm{mL}$

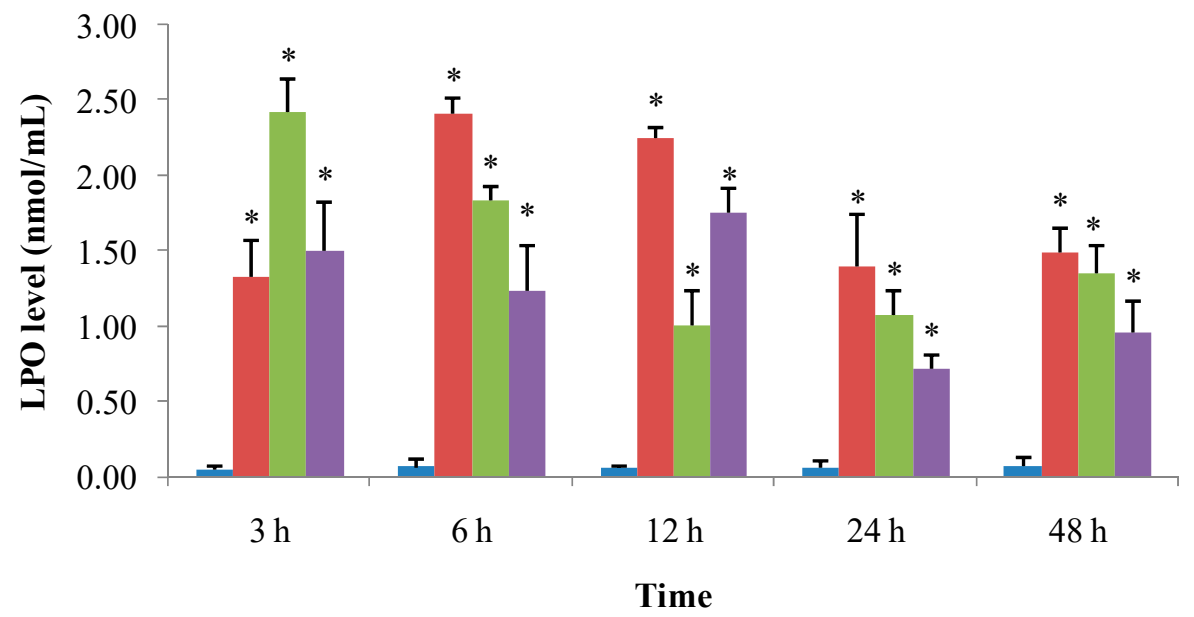

(E) $\quad$ Control $\square 10 \mathrm{ng} / \mathrm{mL} \quad \square 50 \mathrm{ng} / \mathrm{mL} \quad \square 100 \mathrm{ng} / \mathrm{mL}$

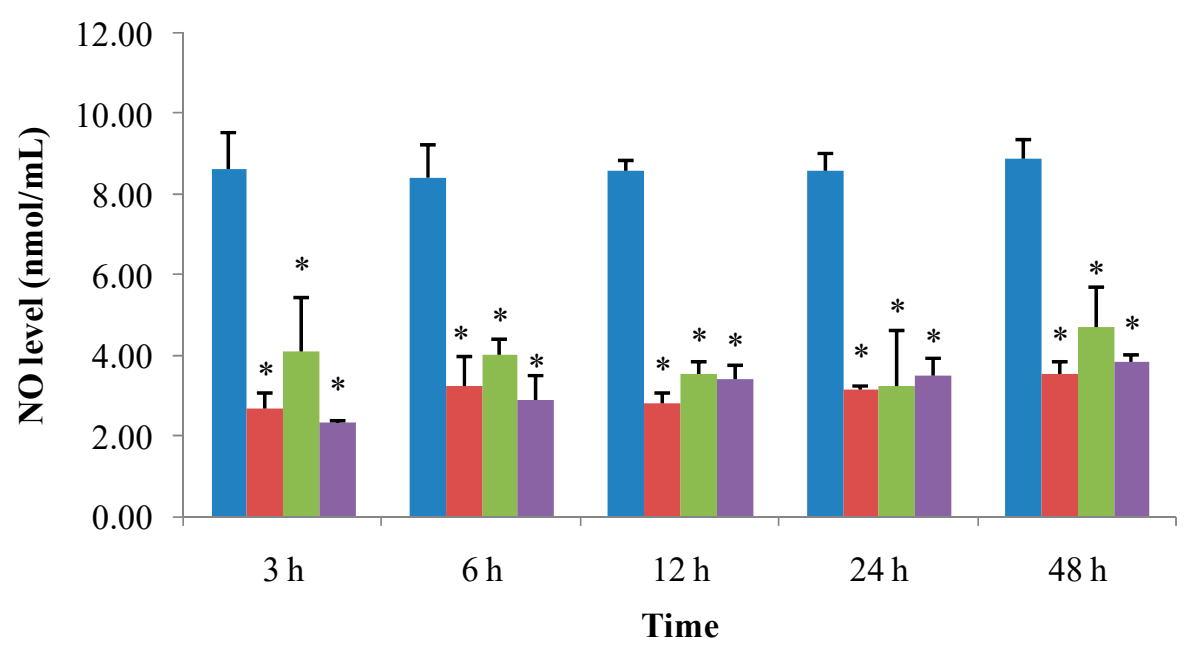

Figure 1. Cont. 
(F)

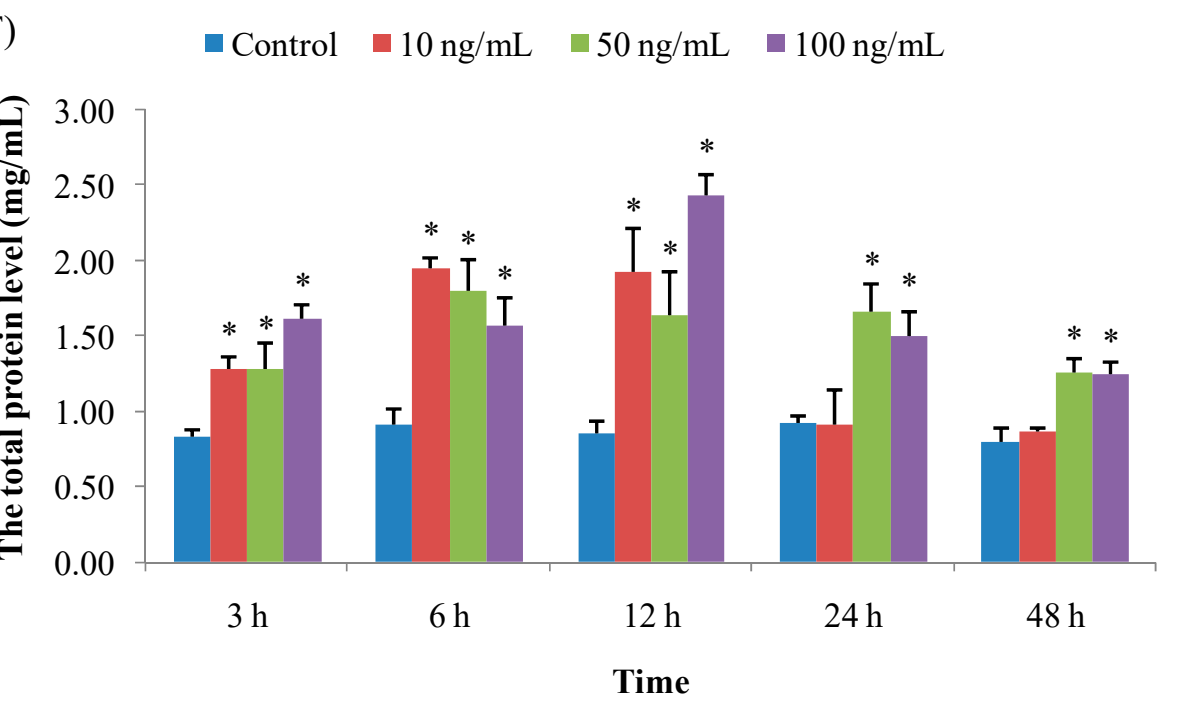

Figure 1. Effects of domoic acid (DA) on non-specific immune responses of the bay scallop Argopecten irradians at different time intervals after exposure to DA at three concentrations $(10,50$, and $100 \mathrm{ng} / \mathrm{mL})$. (A) acid phosphatase (ACP); (B) alkaline phosphatase (ALP); (C) lactate dehydrogenase (LDH); (D) lipid peroxide (LPO); (E) nitric oxide (NO) level; (F) total protein concentration. Data represent mean \pm SD values $(n=3)$ during sampling with " **" denoting significant differences between the treatments of each exposure time $(p<0.05)$.

\subsection{Expression of Immune-Related Genes}

\subsubsection{Expression of CTL6}

CTL6 mRNA levels (Figure 2A) remained almost unchanged in the group treated with $10 \mathrm{ng} / \mathrm{mL}$ of DA at 3-12 hpe; however, CTL6 was significantly upregulated at 24-48 hpe. Accordingly, CTL6 mRNA levels in the $50 \mathrm{ng} / \mathrm{mL}$ DA-treated group were significantly higher than those in the control group at 3-48 hpe, except at 12 hpe, which reverted to baseline levels. CTL6 mRNA expression levels remained almost unchanged on treatment with $100 \mathrm{ng} / \mathrm{mL}$ of DA at 3-6 hpe; however, they were significantly decreased at 12 hpe and sharply increased $(p<0.05)$ at $24-48$ hpe.

\subsubsection{Expression of FREP}

FREP mRNA levels (Figure 2B) in the $10 \mathrm{ng} / \mathrm{mL}$ DA-treated group were significantly increased at 6-24 hpe rather than in the control group and sharply decreased $(p<0.05)$ at 48 hpe. FREP mRNA was strongly induced $(p<0.05)$ at $12 \mathrm{hpe}$ in the $50 \mathrm{ng} / \mathrm{mL}$ of DA group and then decreased markedly at 48 hpe. FREP mRNA expression levels in the $100 \mathrm{ng} / \mathrm{mL}$ DA-treated group were significantly increased at 3 hpe and reverted to baseline levels at $6-24$ hpe; thereafter, they sharply decreased $(p<0.05)$ at 48 hpe.

\subsubsection{Expression of HSP90}

HSP90 mRNA expression levels (Figure 2C), upon treatment with $10 \mathrm{ng} / \mathrm{mL} \mathrm{DA}$, increased significantly at 3-24 hpe and gradually decreased with an increase in the exposure time, followed by a significant reduction in comparison with the control group at 48 hpe. HSP90 mRNA expression upon treatment with $50 \mathrm{ng} / \mathrm{mL}$ DA was significantly increased at $3 \mathrm{hpe}$, followed by a marked reduction at 24-48 hpe. HSP90 mRNA expression levels upon treatment with $100 \mathrm{ng} / \mathrm{mL}$ DA decreased at all time intervals, decreasing significantly at 6-48 hpe. 


\subsubsection{Expression of MT}

MT mRNA levels (Figure 2D) did not differ significantly on treatment with $10 \mathrm{ng} / \mathrm{mL}$ DA at 3-12 hpe; however, they were significantly increased at 24-48 hpe. MT mRNA was significantly upregulated at 3-6 hpe on treatment with $50 \mathrm{ng} / \mathrm{mL}$ DA and then reverted to baseline levels at 12-48 hpe. On treatment with $100 \mathrm{ng} / \mathrm{mL}$ DA, MT mRNA was strongly upregulated $(p<0.05)$ at 3-24 hpe.

\subsubsection{Expression of PGRP}

$P G R P$ mRNA levels (Figure 2E) were significantly increased on treatment with $10 \mathrm{ng} / \mathrm{mL}$ DA at all time intervals. PGRP mRNA expression levels were significantly increased on treatment with $50 \mathrm{ng} / \mathrm{mL}$ DA at 3-12 hpe and then significantly decreased at $24-48$ hpe. On treatment with $100 \mathrm{ng} / \mathrm{mL}$ of DA, MT mRNA was significantly downregulated at 3 hpe and upregulated at 12-48 hpe.

\subsubsection{Expression of PrxV}

$\operatorname{Pr} x \mathrm{~V}$ mRNA levels (Figure 2F) were significantly increase on treatment with $10 \mathrm{ng} / \mathrm{mL}$ DA at 3-24 hpe. On treatment with $50 \mathrm{ng} / \mathrm{mL}$ DA, $\operatorname{Pr} x V$ mRNA was significantly upregulated at 3-12 hpe and then significantly downregulated at $48 \mathrm{hpe}$. PrxV mRNA expression levels did not differ significantly on treatment with $100 \mathrm{ng} / \mathrm{mL}$ DA at 3-6 hpe; however, they were significantly increased at 12-24 hpe and reverted to baseline levels at $48 \mathrm{hpe}$.

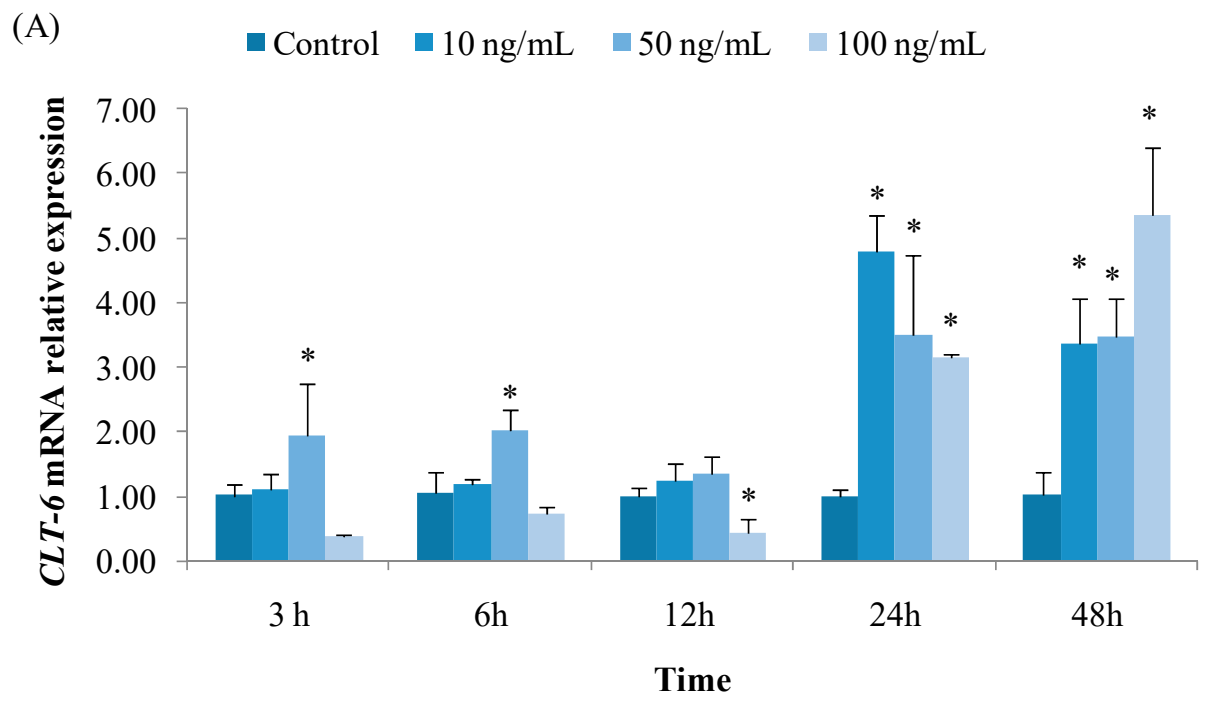

Figure 2. Cont. 
(B) - Control $\square 10 \mathrm{ng} / \mathrm{mL} \quad \square 0 \mathrm{ng} / \mathrm{mL} \quad \square 100 \mathrm{ng} / \mathrm{mL}$

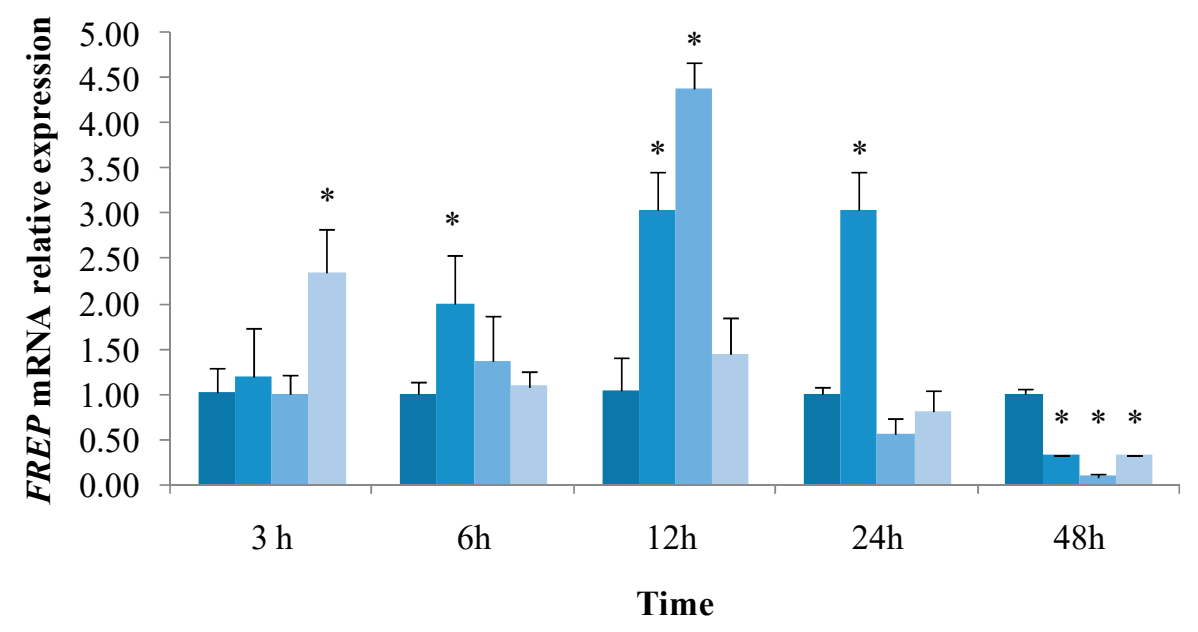

(C) $\square$ Control $\square 10 \mathrm{ng} / \mathrm{mL} \quad \square 50 \mathrm{ng} / \mathrm{mL} \quad \square 100 \mathrm{ng} / \mathrm{mL}$

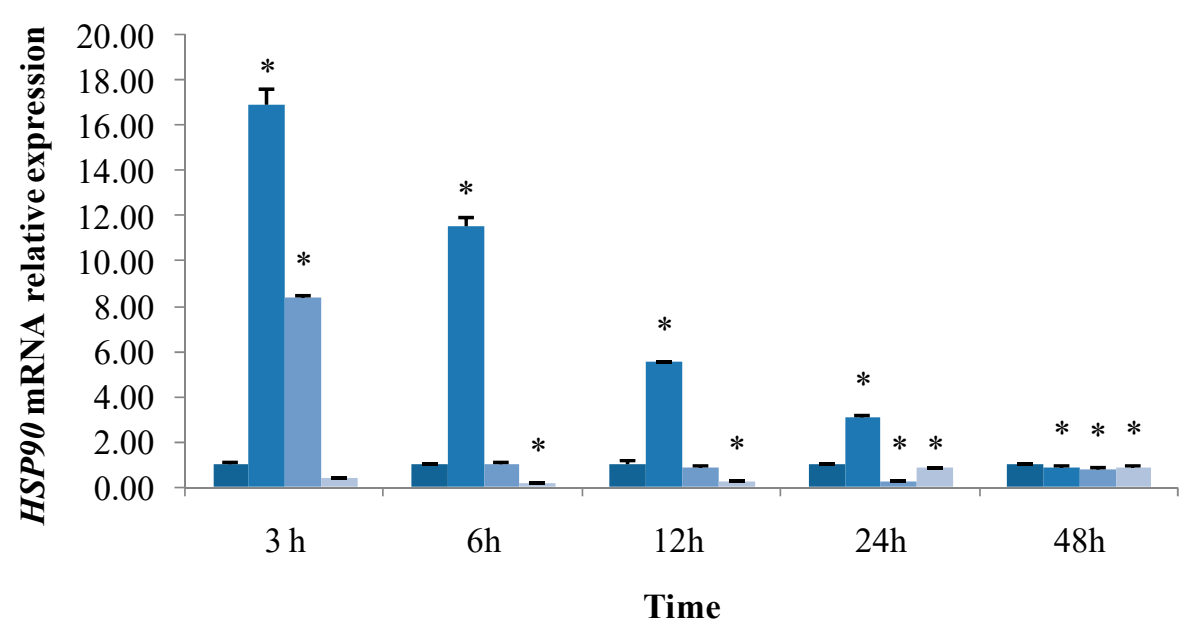

(D) - Control $\quad \square=10 \mathrm{ng} / \mathrm{mL} \quad \square 0 \mathrm{ng} / \mathrm{mL} \quad \square 100 \mathrm{ng} / \mathrm{mL}$

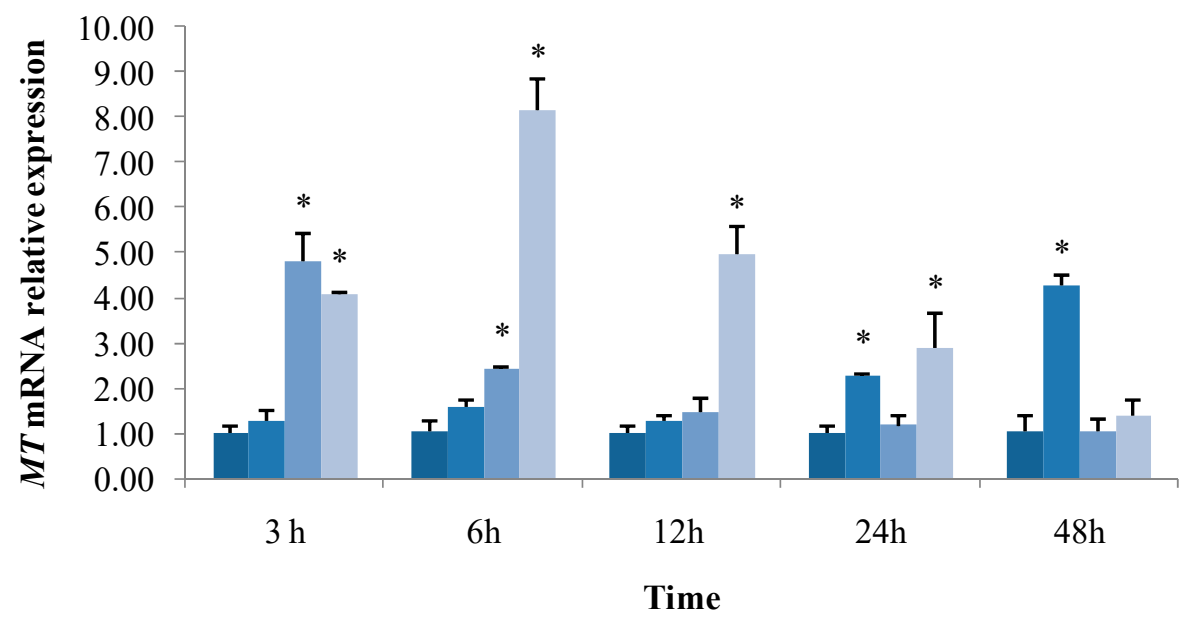

Figure 2. Cont. 
(E)

$$
\text { Control } \square 10 \mathrm{ng} / \mathrm{mL} \quad \square 0 \mathrm{ng} / \mathrm{mL} \quad \square 100 \mathrm{ng} / \mathrm{mL}
$$

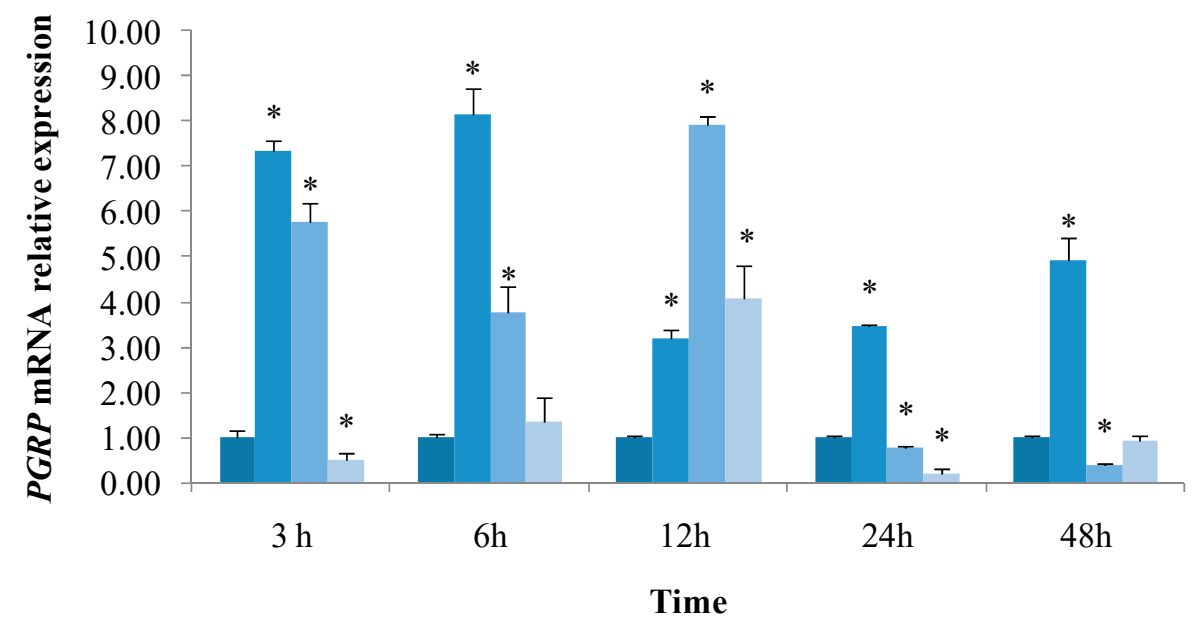

(F) $\quad$ Control $\square 10 \mathrm{ng} / \mathrm{mL} \quad \square 50 \mathrm{ng} / \mathrm{mL} \quad \square 100 \mathrm{ng} / \mathrm{mL}$

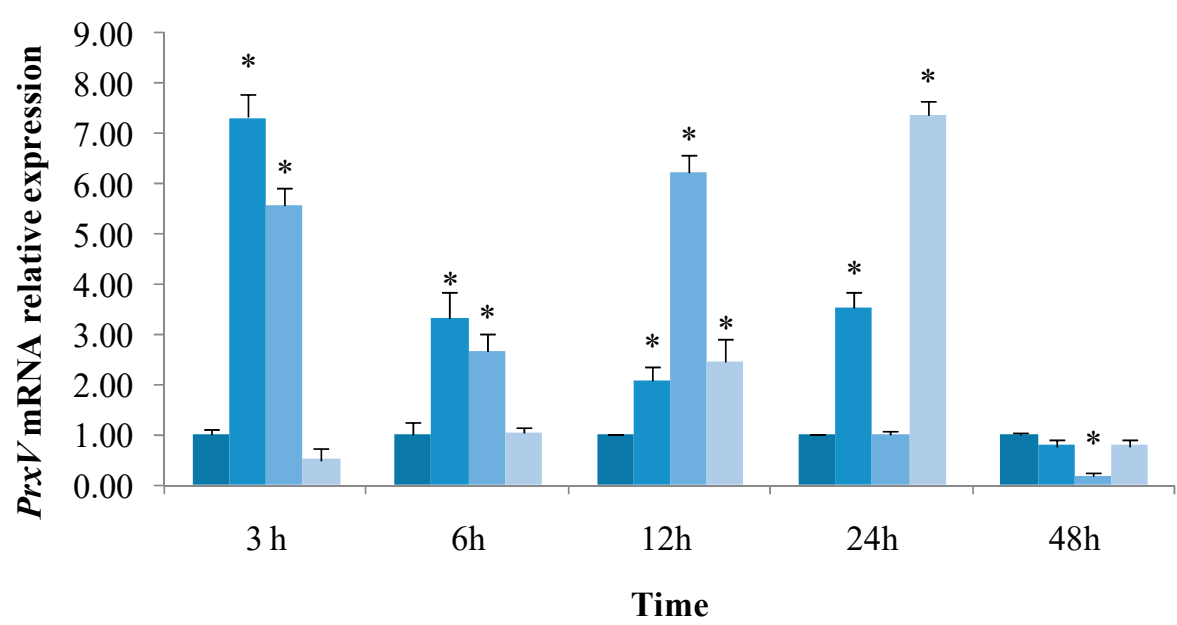

Figure 2. Effects of domoic acid (DA) on non-specific immune responses of the bay scallop Argopecten irradians at different time intervals after exposure to DA at three concentrations $(10,50$, and $100 \mathrm{ng} / \mathrm{mL})$. (A) CLT6; (B) FREP; (C) HSP90; (D) MT; (E) PGRP; (F) PrxV. Data represent mean \pm SD values $(n=3)$ at the same sampling time with "** denoting significant differences the treatments of each exposure time $(p<0.05)$.

\section{Discussion}

DA is an amnesic shellfish poisoning (ASP) toxin, which can be accumulated in the bodies of fish and shellfish [21]. To analyses the effects of DA on scallop physiology and immune-related responses, we assessed some non-specific immune responses and the expression of the immune-related genes in the haemolymph of scallops exposed to different concentrations of DA $(10,50$, and $100 \mathrm{ng} / \mathrm{mL})$. Although continuous high levels of DA exposure, up to $100 \mathrm{ng} / \mathrm{mL}$, is unlikely for scallops in their natural habitat, due to the floating nature of an algal bloom, the relatively high DA concentration used in the present study could help to understand its negative effects as scallops in the natural habitat may be exposed to dissolved DA or toxic algae repeatedly. Scallop may be naturally exposed to 10 and $50 \mathrm{ng} / \mathrm{mL}$ of DA used in this study, as DA at concentrations up to $100 \mathrm{nmol} / \mathrm{L}(=331 \mathrm{ng} / \mathrm{mL}$ ) was occasionally found during natural blooms of Pseudo-nitzschia spp. [22]. The concentrations of dissolved DA (10, 50 and $100 \mathrm{ng} / \mathrm{mL}$ of DA) were used to study DA effects on juvenile king scallop P. maximus [19]. Although few previous investigations studied the DA produced by Pseudo-nitzschia spp., they only 
revealed the accumulation of DA by the sea scallop (Placopecten magellanicus)-fed cultured cells of toxic Pseudo-nitzschia multiseries [23], the effects on immune responses were neglected.

$\mathrm{ACP}$ and ALP are two important hydrolases, which are involved in humoral immune responses and participate in the degradation of xenobiotics by hydrolysis $[10,11]$. In this study, ACP activity was increased after exposure to 10,50 , and $100 \mathrm{ng} / \mathrm{mL}$ of DA at 3-12 hpe in comparison with the control group, concurrent with Jing et al. [24], who reported an increase in ACP activity in Pinctada fucata after exposure to copper. It indicated that external stimulus including DA could induce stronger ACP activity to make phagocytes more effective for opposing and cleaning the DA invasion. However, we observed that ACP activity after exposure to $10 \mathrm{ng} / \mathrm{mL}$ of DA after $6 \mathrm{~h}$ is higher than the activity after exposure to 50 and $100 \mathrm{ng} / \mathrm{mL}$ after the same time; ACP activity after exposure to $100 \mathrm{ng} / \mathrm{mL}$ of DA increases after $3 \mathrm{~h}$ then decrease at $6 \mathrm{~h}$ and increase again after $12 \mathrm{~h}$. It may indicate that higher concentrations or longer time exposure might cause fluctuant $\mathrm{ACP}$ activities with the increase of exposure concentration and extension of time. The induced ACP activity may be attributed to increasing number of lysosomes as a lysosomal ACP enzyme. Whereas, the ACP declining as a response to the increase of exposure concentration and the extension of time, in the current investigation, may be due to decreasing in number of lysosomes and in turn decreased levels of ACP. However, the regulatory mechanism of the fluctuation of ACP activity based on different concentrations and exposure times needs to be further confirmed. Moreover, in the present investigation, the ALP activity was increased in scallop Argopecten irradians after exposure to DA, concurrent with Chi et al. [25], reporting that $500 \mathrm{nM}$ of okadaic acid (OA) significantly induced ALP activity in bay scallops from 12 to $24 \mathrm{hpe}$. These results indicate that scallops treated with DA may resist DA exposure through the increased ACP and ALP activities.

$\mathrm{NO}$ is an important immune signaling molecule in all vertebrates and invertebrates [26] and it is synthesized by inducible (i) NO synthase (iNOS), and usually considered to be related to the immune response in mammals. In bivalves, NO has been demonstrated that it is involved in innate immunity, and be synthesized in scallop hemocytes [17], contributing to pathogen elimination [11]. It is also been demonstrated that NO promotes apoptosis, phagocytic and anti-bacterial ability by developing oxidative toxicity in order to avoid excessive auto-toxicity during the last phase of immunity, playing a crucial role in the modulation of the immune responses. Our results show that NO levels were decreased at all time intervals upon exposure to 10, 50, and $100 \mathrm{ng} / \mathrm{mL}$ DA. Similarly, Barbosa et al. [27] reported that $\mathrm{NO}_{2}{ }^{-}$levels were reduced after the ascidian Styela plicata was exposed to the marine water-soluble fraction of diesel oil (WFDO), indicating a reduction in NO production. Manju et al. [28] demonstrated the protective properties by using a mouse model of DA-induced temporal lobe epilepsy. Therefore, it is speculated that NO may act against DA and the decreasing of NO level may probably due to eliminating DA by combining with it.

LDH is expressed in most living cells, wherein it catalyzes the conversion of pyruvate to lactic acid during carbohydrate metabolism [29]. Therefore, LDH levels reflect the damage to cells, tissues, and organs. Our results show that LDH activity increased after exposure to DA at different concentrations, indicating that DA potentially causes cellular membrane damage in scallops. Ravindran et al. [30] also reported that the LDH activity in U-937 cells was increased significantly after $4 \mathrm{~h}$ of OA exposure and peaked at $16 \mathrm{~h}$. Similarly, Chi et al. [31] reported that scallops treated with higher concentrations of palmitoleic acid (PA) displayed higher LDH activity, potentially resulting in cellular membrane damage. These results are consistent with our present results that $\mathrm{LDH}$ activities were increased after DA exposure, suggesting that DA exposure may induce cellurar membrane damage of hemocytes of bay scallop. Moreover, the previous study reported that the account of hemocytes of the pacific oyster (Crassostrea gigas) increased caused by exposure to DA in the diatom Pseudonitzschia pungens [32]. Therefore, the increasing of activity of LDH in the haemolymph of bay scallop may be also due to the increasing of hemocytes after DA exposure. Moreover, the LDH activities in low concentration of DA $(10 \mathrm{ng} / \mathrm{mL})$ returned to basal level at $24 \mathrm{hpe}$, while in higher concentrations of DA (50 and $100 \mathrm{ng} / \mathrm{mL}$ ) at $48 \mathrm{hpe}$, which is indicating its dose-dependent. LPO is the product of the reaction between oxygen free radicals and polyunsaturated fatty acids. Increased LPO content indicates an excessive amount of 
reactive oxygen species (ROS), which can cause serious damage to lipids and proteins [33]. In this study, LPO levels were increased in all DA-treated groups at all time intervals. Furthermore, Hannam et al. [34] reported a significant increase in LPO after acute oil exposure in Arctic scallop Chlamys islandica. Similarly, these results indicate that DA exposure may induce structural damage to cell membranes, resulting in physiological functional disorders, subsequently decreasing the immunity of bay scallop. Moreover, total protein levels in haemolymph can also reflect the health status of bivalves [35]. Simoes et al. [36] reported a significant increase in the total protein level during the blooms of the toxic alga Dinophysis acuminata in the mussel Perna perna. Consistent with these results, the total protein level in the haemolymph of bay scallop increased upon DA exposure, indicating that DA exposure caused histolysis in the scallop.

C-type lectins potentially recognize and bind to terminal sugars on glycoproteins and glycolipids, and play important roles in non-self-recognition and the elimination of foreign particles [37]. In this study, scallops stimulated with 10 and $50 \mathrm{ng} / \mathrm{mL}$ of DA displayed CLT6 upregulation, while exposure to $100 \mathrm{ng} / \mathrm{mL}$ DA downregulated CLT6 mRNA at 3-12 hpe and upregulated CLT6 at 24-48 hpe, suggesting that low concentrations of DA effectively induce CTL6 expression, and the high CTL6 expression levels result in resistance towards DA toxicity in scallops. However, at higher concentrations, DA potentially inhibits CLT6 expression in a short period, thus negatively impacting immune responses in scallops. On prolonging the exposure duration up to 24-48 h, the CLT6 expression upregulation in the haemolymph of bay scallop was a response to DA invasion. Fibrinogen-related protein (FREP), which is another pattern recognition receptor in innate immune system responses, potentially scavenges xenobiotic substances [38]. In our study, FREP mRNA was expressed at 3-24 hpe after DA exposure; however, it was inhibited in all treatment groups at $48 \mathrm{hpe}$. These results indicate that prolonged exposure to DA inhibits the ability of scallops to recognize and clear xenobiotic particles. Peptidoglycan recognition protein $(P G R P)$ can recognize peptidoglycan and peptidoglycan-containing bacteria and play a major role in recognition and regulation of natural and acquired immune responses [39]. In this study, $10 \mathrm{ng} / \mathrm{mL}$ of DA induced the expression of PGRP mRNA; however, $50 \mathrm{ng} / \mathrm{mL}$ of DA suppressed PGRP expression at 24-48 hpe, indicating that DA at lower concentrations can induce immune responses of scallops to eliminate non-autoimmune substances; however, with an increase in the exposure duration, DA suppressed the immune response in scallops. Moreover, it was speculated that high DA concentrations could suppress the PGRP expression in short period, and then induced to counter DA damage to scallops momentarily, whereas it could inhibit PGRP expression at 48 hpe due to the immune fatigue.

Peroxiredoxins (Prxs) are very important in the antioxidant defense system and can alleviate oxidative damage caused by ROS and regulate oxidative stress levels through $\mathrm{H}_{2} \mathrm{O}_{2}{ }^{-}$mediated signaling [40]. In this study, Prxs was upregulated at 3-24 hpe after exposure to low concentrations of DA. However, on prolonging the exposure duration, Prxs was downregulated in all treatment groups at 48 hpe, suggesting that DA exposure at low concentrations and for short durations potentially induces resistance to oxidative stress induced by DA. However, on prolonged DA exposure, Prxs expression was inhibited, thus weakening the ability of scallops to resist oxidative stresses induced by DA exposure. In addition, heat shock proteins ( $H S P S$ ) are crucial to prevent irreversible protein denaturation, promoting either repair or destruction of damaged proteins [41]. Our results show that DA at lower concentrations induced HSPs in a short period; however, on prolonged exposure and an increase in DA concentration, HSP expression was significantly inhibited. These results indicate that DA might reduce antioxidant buffering capacity, subsequently protein damage in scallops in a doseand time-dependent manner. Metallothionein (MT) plays an important role in responses to oxidative stress, tissue injury, infection, and inflammation [26,42,43]. In this study, MT mRNA was upregulated in scallops after exposure to higher concentrations of DA up to $24 \mathrm{hpe}$. Similarly, Chi et al. [44] reported that scallops treated with PA displayed higher MT expression. This phenomenon may be attributed to more rapid induction of $M T$ mRNA expression by higher concentrations of DA exposure to counter tissue injury or oxidative stress. 
In conclusion, this study showed that exposure to DA at different concentrations markedly influenced physiological and immune responses of the bay scallop, as reflected through ACP, ALP, and $\mathrm{LDH}$ activities and LPO, NO, and TP content, along with immune-related gene expression, showing that DA disrupts immune signaling and physiological phenomena in the bay scallop. The present results potentially provide preliminary evidence regarding the early responses or adaptation of bay scallops with novel insights into the immunotoxicity of DA in scallops and provides a theoretical basis to develop countermeasures against DA to subsequently improve the production efficiency during scallop culture. However, the effects of DA exposure on oxidative stresses or apoptosis as well as DA accumulation in haemolymph of bay scallop after different concentrations of DA exposure, as well as the regulatory mechanism of these physiological and immune processes based on different concentration and exposure time needs to be further confirmed, should be investigated further.

Author Contributions: Investigation, C.Z.; resources, J.L.; X.Z.; data curation, C.C.; writing-original draft preparation, C.Z.; C.C. writing-review and editing, C.C. funding acquisition, C.C.

Funding: This work was supported by the National Natural Science Foundation of China [Grant No.: 31802347], and the Fundamental Research Funds for the Central Universities [Grant No.: KJQN201937].

Conflicts of Interest: The authors declare no conflict of interest. The funding sponsors had no role in the design of the study; in the collection, analyses, or interpretation of data; in the writing of the manuscript, and in the decision to publish the results.

\section{References}

1. Mazmanc1, B.; Çavas, T. Antioxidant enzyme activity and lipid peroxidation in liver and gill tissues of Nile tilapia (Oreochromis niloticus) following in vivo exposure to domoic acid. Toxicon 2010, 55, 734-738. [CrossRef] [PubMed]

2. Lopes, V.M.; Lopes, A.R.; Costa, P.; Rosa, R. Cephalopods as vectors of harmful algal bloom toxins in marine food webs. Mar. Drugs 2013, 11, 3381-3409. [CrossRef] [PubMed]

3. Ventoso, P.; Pazos, A.J.; Pérez-Parallé, M.L.; Blanco, J.; Triviño, J.C.; Sánchez, J.L. RNA-Seq transcriptome profiling of the queen scallop (Aequipecten opercularis) digestive gland after exposure to domoic acid-producing Pseudo-nitzschia. Toxins 2019, 11, 97. [CrossRef] [PubMed]

4. Lefebvre, K.A.; Robertson, A. Domoic acid and human exposure risks: A review. Toxicon 2010, 56, $218-230$. [CrossRef]

5. Lefebvre, K.A.; Tilton, S.C.; Bammler, T.K.; Beyer, R.P.; Srinouanprachan, S.; Stapleton, P.L.; Farin, F.M.; Gallagher, E.P. Gene expression profiles in zebrafish brain after acute exposure to domoic acid at symptomatic and asymptomatic doses. Toxicol. Sci. 2009, 107, 65-77. [CrossRef]

6. Nogueira, I.; Lobo-da-Cunha, A.; Afonso, A.; Rivera, S.; Azevedo, J.; Monteiro, R.; Cervantes, R.; Gago-Martinez, A.; Vasconcelos, V. Toxic effects of domoic acid in the seabream Sparus aurata. Mar. Drugs 2010, 8, 2721-2732. [CrossRef]

7. Zabaglo, K.; Chrapusta, E.; Bober, B.; Kaminski, A.; Adamski, M.; Bialczyk, J. Environmental roles and biological activity of domoic acid: A review. Algal Res. 2016, 13, 94-101. [CrossRef]

8. Pazos, A.J.; Ventoso, P.; Martínez-Escauriaza, R.; Pérez-Parallé, M.L.; Blanco, J.; Triviño, J.C.; Sánchez, J.L. Transcriptional response after exposure to domoic acid-producing Pseudo-nitzschia in the digestive gland of the mussel Mytilus galloprovincialis. Toxicon 2017, 140, 60-71. [CrossRef]

9. Song, L.S.; Wang, L.L.; Zhang, H.; Wang, M.Q. The immune system and its modulation mechanism in scallop. Fish. Shellfish Immunol. 2015, 46, 65-78. [CrossRef]

10. Suresh, K.; Mohandas, A. Hemolymph acid phosphatase activity pattern in copper-stressed bivalves. J. Invertebr. Pathol. 1990, 55, 118-125. [CrossRef]

11. Chi, C.; Yun, S.; Giri, S.S.; Kim, H.J.; Kim, S.W.; Kang, J.W.; Park, S.C. Effect of the algicide thiazolidinedione 49 on immune responses of bay scallop Argopecten Irradians. Molecules 2019, 24, 3579. [CrossRef] [PubMed]

12. Cheng, T.C. The Role of Lysosomal Hydrolases in Molluscan Cellular Response to Immunologic Challenge, 1st ed.; Springer: Boston, MA, USA, 1978; pp. 59-71.

13. Chi, C.; Giri, S.S.; Jun, J.W.; Kim, H.J.; Yun, S.; Kim, S.G.; Park, S.C. Marine toxin okadaic acid affects the immune function of bay scallop (Argopecten irradians). Molecules 2016, 21, 1108. [CrossRef] [PubMed] 
14. Wu, A.H.; Wan, P.; Bernstein, L. A multiethnic population-based study of smoking, alcohol and body size and risk of adenocarcinomas of the stomach and esophagus (United States). Cancer Causes Control 2001, 12, 721-732. [CrossRef] [PubMed]

15. Jiang, Q.; Zhou, Z.; Wang, L.L.; Shi, X.W.; Wang, J.J.; Yue, F.; Yi, Q.L.; Yang, C.Y.; Song, L.S. The immunomodulation of inducible nitric oxide in scallop Chlamys farreri. Fish. Shellfish Immunol. 2013, 34, 100-108. [CrossRef]

16. Jiang, Q.; Zhou, Z.; Wang, L.L.; Wang, L.L.; Yue, F.; Wang, L.L.; Song, L.S. A scallop nitric oxide synthase (NOS) with structure similar to neuronal NOS and its involvement in the immune defense. PLOS ONE 2013, 8, e69158. [CrossRef]

17. Franchini, A.; Fontanili, P.; Ottaviani, E. Invertebrate immunocytes: Relationship between phagocytosis and nitric oxide production. Comp. Biochem. Physiol. B 1995, 110, 403-407. [CrossRef]

18. Gao, Q.; Zhao, J.M.; Song, L.S.; Qiu, L.M.; Yu, Y.D.; Zhang, H.; Ni, D.J. Molecular cloning, characterization and expression of heat shock protein 90 gene in the haemocytes of bay scallop Argopecten irradians. Fish. Shellfish Immunol. 2008, 24, 379-385. [CrossRef]

19. Liu, H.; Kelly, M.S.; Campbell, D.A.; Fang, J.G.; Zhu, J.X. Accumulation of domoic acid and its effect on juvenile king scallop Pecten maximus (Linnaeus, 1758). Aquaculture 2008, 284, 224-230. [CrossRef]

20. Livak, K.J.; Schmittgen, T.D. Analysis of relative gene expression data using real-time quantitative PCR and the $2^{-\Delta \Delta C T}$ method. Methods 2001, 25, 402-408. [CrossRef]

21. Todd, E.C.D. Domoic acid and amnesic shellfish poisoning-A review. J. Food Prot. 1993, 56, 69-83. [CrossRef]

22. Wells, M.L.; Trick, C.G.; Cochlan, W.P.; Hughes, M.P.; Trainer, V.L. Domoic acid: The synergy of iron, copper, and the toxicity of diatoms. Limnol. Oceanogr. 2005, 50, 1908-1917. [CrossRef]

23. Douglas, D.J.; Kenchington, E.R.; Bird, C.J.; Pocklington, R.; Bradford, B.; Silvert, W. Accumulation of domoic acid by the sea scallop (Placopecten magellanicus) fed cultured cells of toxic Pseudo-nitzschia multiseries. Fish. Aquat. Sci. 1997, 54, 907-913. [CrossRef]

24. Jing, G.; Li, Y.; Xie, L.; Zhang, R. Metal accumulation and enzyme activities in gills and digestive gland of pearl oyster (Pinctada fucata) exposed to copper. Comp. Biochem. Physiol. C 2006, 144, 184-190. [CrossRef] [PubMed]

25. Chi, C.; Giri, S.S.; Jun, J.W.; Kim, H.J.; Kim, S.W.; Yun, S.; Park, S.C. Effects of algal toxin okadaic acid on the non-specific immune and antioxidant response of bay scallop (Argopecten irradians). Fish. Shellfish Immunol. 2017, 65, 111-117. [CrossRef] [PubMed]

26. Gestal, C.; Roch, P.; Renault, T.; Pallavicini, A.; Paillard, C.; Novoa, B.; Oubella, R.; Venier, P. Study of diseases and the immune system of bivalves using molecular biology and genomics. Rev. Fish. Sci. 2008, 16, 131-154. [CrossRef]

27. Barbosa, D.B.; Mello, A.D.A.; Allodi, S.; Barros, C.M.D. Acute exposure to water-soluble fractions of marine diesel oil: Evaluation of apoptosis and oxidative stress in an ascidian. Chemosphere 2018, 211, 308-315. [CrossRef]

28. Pande, M.; Harps, A.; Sundaram, M.; Vig, P.J.S. Role of nitric oxide in domoic acid induced hippocampal degeneration. J. Neurol. Sci. Turk. 2007, 24, 16-24.

29. Senthil-Nathan, S.; Kalaivani, K.; Chung, P.G.; Murugan, K. Effect of neem limonoids on lactate dehydrogenase (LDH) of the rice leaffolder, Cnaphalocrocis medinalis (Guenée) (Insecta: Lepidoptera: Pyralidae). Chemosphere 2006, 62, 1388-1393. [CrossRef]

30. Ravindran, J.; Gupta, N.; Agrawal, M.; Bhaskar, A.B.; Rao, P.L. Modulation of ROS/MAPK signaling pathways by okadaic acid leads to cell death via, mitochondrial mediated caspase-dependent mechanism. Apoptosis 2011, 16, 145-161. [CrossRef]

31. Chi, C.; Giri, S.S.; Jun, J.W.; Yun, S.; Kim, H.J.; Kim, S.G.; Park, S.C. Immune response of the bay scallop, Argopecten irradians, after exposure to the algicide palmitoleic acid. Fish. Shellfish Immunol. 2016, 57, 371-378. [CrossRef]

32. Jones, T.O.; Whyte, J.N.C.; Townsend, L.D.; Ginther, N.G.; Iwama, G.K. Effects of domoic acid on haemolymph $\mathrm{pH}, \mathrm{PCO}_{2}$ and $\mathrm{PO}_{2}$ in the Pacific oyster, Crassostrea gigas and the California mussel, Mytilus californianus. Aquat. Toxicol. 1995, 31, 43-55. [CrossRef]

33. Hannam, M.L.; Bamber, S.D.; Moody, A.J.; Galloway, T.S.; Jones, M.B. Immune function in the Arctic Scallop, Chlamys islandica, following dispersed oil exposure. Aquat. Toxicol. 2009, 92, 187-194. [CrossRef] [PubMed] 
34. Hannam, M.L.; Bamber, S.D.; Moody, A.J.; Galloway, T.S.; Jones, M.B. Immunotoxicity and oxidative stress in the Arctic scallop Chlamys islandica: Effects of acute oil exposure. Ecotox. Environ. Saf. 2010, 73, 1440-1448. [CrossRef] [PubMed]

35. Mello, D.F.; Proença, L.A.; Barracco, M.A. Comparative study of various immune parameters in three bivalve species during a natural bloom of Dinophysis acuminata in Santa Catarina Island, Brazil. Toxins 2010, 2, 1166-1178.

36. Simões, E.; Vieira, R.C.; Schramm, M.A.; Mello, D.F.; Pontinha, V.D.A.; Silva, P.M.D.; Barracco, M.A. Impact of harmful algal blooms (Dinophysis acuminata) on the immune system of oysters and mussels from Santa Catarina, Brazil. J. Mar. Biol. Assoc. UK 2015, 95, 773-781. [CrossRef]

37. Manfrin, C.; Dreos, R.; Battistella, S.; Beran, A. Mediterranean mussel gene expression profile induced by okadaic acid exposure. Environ. Sci. Technol. 2010, 44, 8276-8283. [CrossRef]

38. Zhang, H.; Wang, L.L.; Song, L.S.; Song, X.Y.; Wang, B.; Mu, C.K.; Zhang, Y. A fibrinogen-related protein from bay scallop Argopecten irradians involved in innate immunity as pattern recognition receptor. Fish. Shellfish Immunol. 2009, 26, 56-64. [CrossRef]

39. Ni, D.J.; Song, L.S.; Wu, L.T.; Chang, Y.Q.; Yu, Y.D.; Qiu, L.M.; Wang, L.L. Molecular cloning and mRNA expression of peptidoglycan recognition protein (PGRP) gene in bay scallop (Argopecten irradians, Lamarck 1819). Dev. Comp. Immunol. 2006, 31, 548-558. [CrossRef]

40. Li, J.; Li, L.; Zhang, S.; Zhang, G.F. Cloning, genomic structure, and expression analysis of peroxiredoxin V from bay scallop Argopecten irradians. Fish. Shellfish Immunol. 2011, 30, 309-316. [CrossRef]

41. Regoli, F.; Giuliani, M.E. Oxidative pathways of chemical toxicity and oxidative stress biomarkers in marine organisms. Mar. Environ. Res. 2014, 93, 106-117. [CrossRef]

42. Miles, A.T.; Hawksworth, G.M.; Beattie, J.; Rodilla, V. Induction, regulation, degradation, and biological significance of mammalian metallothioneins. CRC Crit. Rev. Biochem. 2000, 35, 35-70. [CrossRef] [PubMed]

43. Wang, L.; Song, L.S.; Ni, D.J.; Zhang, H.; Liu, W.Q. Alteration of metallothionein mRNA in bay scallop Argopecten irradians under cadmium exposure and bacteria challenge. Comp. Biochem. Physiol. C 2008, 149, 50-57. [CrossRef] [PubMed]

44. Chi, C.; Giri, S.S.; Jun, J.W.; Kim, H.J. Effect of the algaecide palmitoleic acid on the immune function of the bay scallop Argopecten irradians. Molecules 2016, 21, 610. [CrossRef] [PubMed]

(C) 2019 by the authors. Licensee MDPI, Basel, Switzerland. This article is an open access article distributed under the terms and conditions of the Creative Commons Attribution (CC BY) license (http://creativecommons.org/licenses/by/4.0/). 